\title{
WATERMELON FRUITS PROPERTIES AS AFFECTED BY STORAGE CONDITIONS
}

\author{
El-Sayed G. Khater* and Adel H. Bahnasawy**
}

\begin{abstract}
The main objective of this article was to study the physical and mechanical properties of watermelon fruits as influenced by storage temperatures. Watermelon fruits with different sizes were stored at two temperatures $\left(15\right.$ and $\left.30^{\circ} \mathrm{C}\right)$. The results indicated that, the length, major diameter and minor diameter of watermelon fruit value ranged from 22.18 to $28.77 \mathrm{~cm}, 21.34$ to $27.07 \mathrm{~cm}$ and 18.92 to $23.01 \mathrm{~cm}$, respectively. The spherical coefficient and the geometric mean diameter of the watermelon fruits decreased from 0.933 to 0.907 and 20.70 to $26.08 \mathrm{~cm}$, respectively. The surface area and volume of watermelon fruit values ranged from 1487.10 to $2447.61 \mathrm{~cm}^{2}$ and 5393.90 to $11389.44 \mathrm{~cm}^{3}$, respectively. The density of the watermelon fruits ranged from 927.84 to $973.57 \mathrm{~kg} \mathrm{~m}^{-3}$. The thickness of rind of the watermelon fruits ranged from 12.11 to $20.28 \mathrm{~mm}$. The mass of flesh, seeds and rind of watermelon fruit values ranged from 2.929 to $6.277 \mathrm{~kg}, 0.096$ to $0.208 \mathrm{~kg}$ and 1.992 to $4.603 \mathrm{~kg}$, respectively. The repose angle and the crushing load of the watermelon fruits increased from 49.67 to $71.00^{\circ}$ and 2.333 to $4.600 \mathrm{kN}$. The change of watermelon fruits dimensions and weight decreased with increasing storage temperature and time. The crushing load of the watermelon fruits decreases with decreasing storage temperature and decreasing watermelon fruit sizes. The marketable watermelon fruits percentage ranged from 75.67 to $90.00 \%$ at $15{ }^{\circ} \mathrm{C}$ and from 25.00 to $48.00 \%$ at $30^{\circ} \mathrm{C}$.
\end{abstract}

Keywords: watermelon, properties, dimensions, storage temperature, marketable

*Lecturer, Agricultural Engineering Department - Faculty of Agriculture - Benha University, Egypt - E-mail address: alsayed.khater@fagr.bu.edu.eg

**Professor, Agricultural Engineering Department - Faculty of Agriculture Benha University, Egypt - E-mail address: adel.bahnasawy@fagr.bu.edu.eg 


\section{INTRODUCTION}

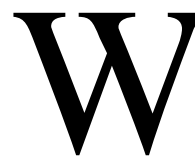

atermelon is one of the most important economic vegetable crops, practiced by the Egyptian farmers. The total cultivated area of watermelon is about 160000 Faddens (67200 ha) (GAEO, 2013). Watermelon has large, round, oval or oblong fruit shape with very rich source of vitamins. It can be used for breakfast as appetizer or snack (Salk et al., 2008). It is also as a good source of phyto-chemical and lycopene, a red carotene pigment which acts as antioxidant during normal metabolism and protects against cancer (Perkins and Collins, 2004). According to Bawa and Bains (1977), Hour et al., (1980) and Ahmed (1996), the juice or pulp from watermelon is used for human consumption, while rind and seeds are major solid wastes (Koocheki $\boldsymbol{e t}$ al., 2007).

Watermelons were first grown in Egypt nearly 5,000 years ago. They were placed in tombs of kings to provide nourishment for the afterlife. Pictures of watermelons have even been noted in ancient Egyptian hieroglyphics. Watermelons were introduced to China in the 10th century, and eventually made their way west to North America (Anonymous, 2014).

Knowledge of length, width, volume, surface area and weight of the product is necessary to: (a) the design of sorting and grading machines (b) predicting amounts of surface applied chemicals and (c) describing heat and mass transfer during thermal processes and in quantification of bruise, abrasion and damage in handling process. The shape of some fruits is important in determining their suitability for processing as well as their retail value. Many researches have been carried out on the physical and engineering properties of many agricultural products (Irvine et al., 1992; El-Raie et al., 1996; Bahnasawy et al., 2004). The information on size, density, and crushing strength are required for the development of grading system for barriers and for the pulpers (Gosh, 1969). The physical and mechanical properties such as size, friction angle, angle of repose, crushing strength and bulk density are important in the design of 
the handling system and grading (Chandrasekar and Viswanathan, 1999).

Watermelons generally are not refrigerated when shipped domestically. However, refrigerated storage and transit may be used to extend the shelf life during export shipment. The recommended range is 10 to $15^{\circ} \mathrm{C}$ (Hardenburg et al., 1986). At lower temperatures, fruit are susceptible to chilling injury and decay (Dow et al., 1979) and loss of color (Showalter, 1960). At higher temperatures, fruit are subject to decay (Leupeschen, 1961) and sugar loss (Chisholm and Picha, 1986). Prestorage conditioning at $26^{\circ} \mathrm{C}$ for 4 days reduces development of chilling injury and increases the percentage of marketable fruit following storage (Picha, 1986).

Fresh fruits and vegetables probably receive the greatest temperature abuse at the retail level. Temperature abuse is a function of time and temperature during holding and the relative perishability of a particular commodity. For examples, apples and cabbages are often displayed at improper temperature at retail but they do not lose quality rapidly when compared to strawberries or broccoli. Mean temperatures of display cases used for fruits and vegetable are 7.6 and $8.4^{\circ} \mathrm{C}$ in winter and summer, respectively (LeBlanc et al., 1996). The majority (90\%) of those commodities that should have been stored at less than or equal to $4{ }^{\circ} \mathrm{C}$ were above the recommended temperature range. The same percentage was found for commodities that should have been held greater than or equal to $12^{\circ} \mathrm{C}$. The significance of laboratory studies and to a lesser extent simulated shipping studies may therefore not be relevant to commercial practices in many cases. Broccoli held under simulated retail display and overnight storage treatments showed considerable reduction in shelf life and indicate the possible extent of the commercial retail handling problem (Perrin and Gaye, 1986).

Handling and processing of watermelon fruits is very teddies work due to the big size of fruits, which need accurate information about the physical and mechanical properties, therefore, this article aimed to study some physical and mechanical properties as influenced by storage temperatures. 


\section{MATERIALS AND METHODS}

The experiment was carried out at Agricultural Engineering Department, Faculty of Agriculture, Moshtohor, Benha University, during the period of June to August, 2014.

\subsection{Materials:}

Watermelon (Citrullus lanatus, Thumb.) was brought from the local market after harvesting with the same maturity stage (the price of one ton equal L.E 2000), then inspected and graded into three categories [5 kg (small), $8 \mathrm{~kg}$ (medium) and $11 \mathrm{~kg}$ (large)]. These categories were used to measure and determine the physical and mechanical properties.

\subsection{Methods:}

\subsubsection{Physical and mechanical properties:}

\subsubsection{Physical properties:}

The dimensions of watermelon fruits (length, major diameter and minor diameter) were measured by tape. Geometric mean diameters and spherical coefficient were determined from equations (1 and 2) (Sadrnia et al., 2006).

$$
\begin{aligned}
& \text { Geometric mean diameters }=\sqrt[3]{a b c} \\
& \text { Spherical coefficien } \mathrm{t}=\frac{\sqrt[3]{\mathrm{abc}}}{a}
\end{aligned}
$$

Where:-

$\mathrm{a}$ is the length of watermelon fruits, $\mathrm{cm}$.

$\mathrm{b}$ is the major diameter of watermelon fruits, $\mathrm{cm}$,

$\mathrm{c}$ is the minor diameter of watermelon fruits, $\mathrm{cm}$.

The thickness of rind was measured by digital vernier caliper (Model TESA 1p65- Range 0-150 $\mathrm{mm} \pm 0.01 \mathrm{~mm}$, Swiss). The mass was measured by electric digital balance (Model Vibra - Range 0-12000 g \pm $0.01 \mathrm{~g}$, Japan). The surface area was measured by wrapping aluminum foil around the cucumber fruit and then cutting the foil away with scissors into thin strips sufficient to lay the foil flat. A planimeter (Model Placom KP -90 N- Range 0-10 m2 $\pm 0.2 \%$, Japan) was used to measure the surface area of the cucumber. The volume of fruits was measured by graduated cylinder. 
The moisture content of randomly selected watermelon fruits (flesh, seeds and rind) of each category was determined according to ASAE Standard (1984). Three samples of each watermelon fruits were randomly selected and weighed on an electric digital balance. Drying oven (Fisher Scientific Isotemp Oven, Model 655F Cat. No. 13-245-655, Fisher Scientific, Toronto, Ontario, Canada) at $105^{\circ} \mathrm{C}$ until a constant weight was used to measure the moisture content.

The bulk density was a measurement of a watermelon fruits mass per unit volume. For each case, the determination was replicated three times and the mean was considered.

\subsubsection{Mechanical Properties:}

The angle of repose is the minimum angle at which any piled-up bulky or loose material will stand without falling downhill.

Crushing load implies the partial or complete destruction of watermelon fruits. Crushing load was measured by compressive and tensile device loads ((Model MP2E- Range 0-2000 kN $\pm 0.1 \mathrm{kN}$, Italy)

\subsubsection{Storage conditions:}

The watermelon fruits were stored at two temperature $15^{\circ} \mathrm{C}(85 \pm$ $5 \%$ relative humidity) and room temperature $30 \pm 3^{\circ} \mathrm{C}(60 \pm 5 \%$ relative humidity). The dimensions, mass, surface area, volume and bulk density were measured every five days. The thickness of rind, moisture content and crushing load were measured at the end of the experiment. These measurements were repeated three times and the average was taken.

\subsection{Statistical analysis:}

The statistical analysis for the data obtained was done according to Snedecor and Cochran (1980) and the treatments were compared using at 0.05 level probability.

\section{RESULTS AND DISCUSSIONS}

\subsection{Physical properties}

Table (1) shows the dimensions (length, major diameter and minor diameter), spherical coefficient and geometric mean diameter of the watermelon fruits. It could be seen that the length, major diameter and minor diameter of watermelon fruit value ranged from $22.18 \pm 0.185$ to $28.77 \pm 0.185 \mathrm{~cm}, 21.34 \pm 0.102$ to $27.07 \pm 0.012 \mathrm{~cm}$ and $18.92 \pm 0.060$ to $23.01 \pm 0.414 \mathrm{~cm}$, respectively, for different sizes of watermelon fruits. 
The highest value of length, major diameter and minor diameter of watermelon fruits were $28.77,27.07$ and $23.01 \mathrm{~cm}$, respectively, were found for large size, while, the lowest value of length, major diameter and minor diameter of watermelon fruits were $22.18,21.34$ and $18.92 \mathrm{~cm}$, respectively, were obtained for small size of watermelon fruits. These dimension data are very important in storage capacity determination, for example, the volumes required to storage one ton for the small, medium and large sizes were $2.03,1.96$ and $1.90 \mathrm{~m}^{3}$, respectively. Figures $(1 \mathrm{a}, \mathrm{b}$ and c) show the frequency distribution of the dimensions of the watermelon fruits.

Table (1): The mean, standard deviation and coefficient of variation for some physical properties of watermelon fruits.

\begin{tabular}{|c|c|c|c|c|c|c|}
\hline \multicolumn{2}{|c|}{ Watermelon size } & \multicolumn{3}{|c|}{ Dimensions } & \multirow{3}{*}{$\begin{array}{c}\text { Spherical } \\
\text { coefficient } \\
0.933 \\
\end{array}$} & \multirow{3}{*}{$\begin{array}{c}\text { Geometric mean } \\
\text { diameter, } \mathrm{cm} \\
20.70 \\
\end{array}$} \\
\hline & & Length, $\mathrm{cm}$ & $\begin{array}{l}\text { Major diameter, } \\
\mathrm{cm}\end{array}$ & $\begin{array}{l}\text { Minor diameter, } \\
\mathrm{cm}\end{array}$ & & \\
\hline \multirow{3}{*}{$\begin{array}{l}\text { Small } \\
\text { Size }\end{array}$} & Mean & 22.18 & 21.34 & 18.92 & & \\
\hline & SD & 0.185 & 0.102 & 0.060 & 0.004 & 0.074 \\
\hline & $\mathrm{CV}$ & 0.008 & 0.005 & 0.003 & 0.005 & 0.004 \\
\hline \multirow{3}{*}{$\begin{array}{l}\text { Medium } \\
\text { Size }\end{array}$} & Mean & 25.59 & 24.20 & 20.50 & 0.909 & 23.26 \\
\hline & SD & 0.185 & 0.099 & 0.0415 & 0.014 & 0.211 \\
\hline & $\mathrm{CV}$ & 0.007 & 0.315 & 0.020 & 0.015 & 0.009 \\
\hline \multirow{3}{*}{$\begin{array}{l}\text { Large } \\
\text { Size }\end{array}$} & Mean & 28.77 & 27.07 & 23.01 & 0.907 & 26.08 \\
\hline & SD & 0.185 & 0.320 & 0.414 & 0.012 & 0.210 \\
\hline & $\mathrm{CV}$ & 0.006 & 0.012 & 0.018 & 0.014 & 0.008 \\
\hline
\end{tabular}

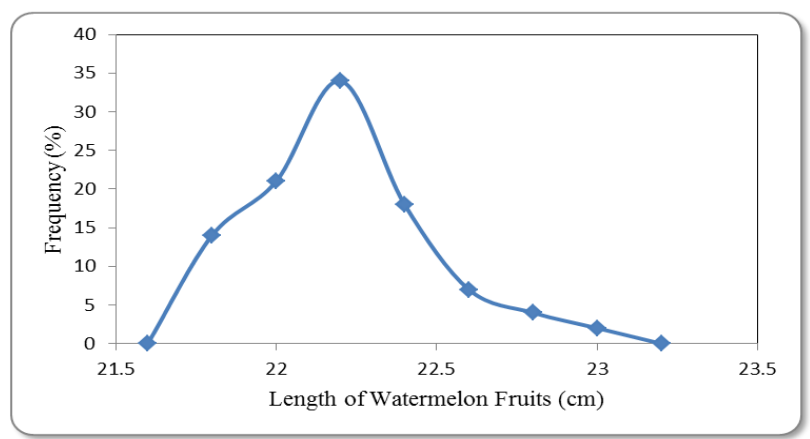

Figure (1a): The frequency distribution of the length of the watermelon fruits 


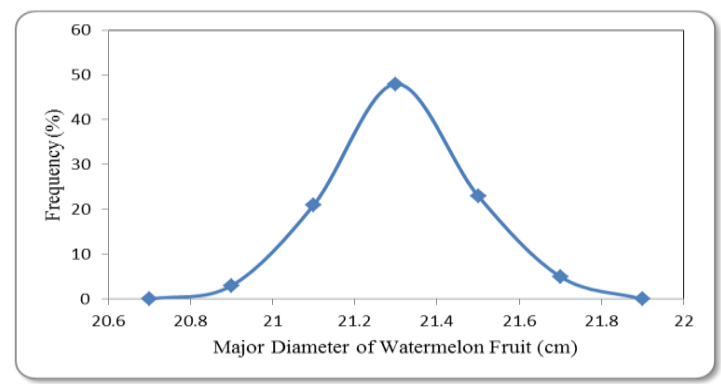

Figure (1b): The frequency distribution of the major diameter of the watermelon fruits

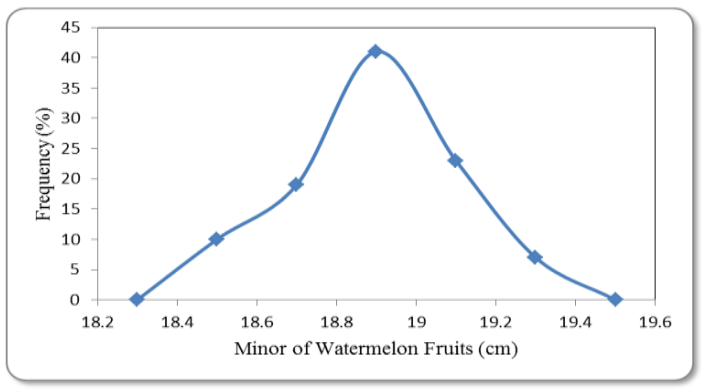

Figure (1c): The frequency distribution of the minor diameter of the watermelon fruits

The results indicated that the spherical coefficient of the watermelon fruits decreases with increasing the watermelon fruits sizes. It indicated that when the watermelon fruits size varies from small size $(5.0 \mathrm{~kg})$ to large size $(11.0 \mathrm{~kg})$, the spherical coefficient of the watermelon fruits decreased from $0.933 \pm 0.004$ to $0.907 \pm 0.012$. The results also indicated that the geometric mean diameter of the watermelon fruits increases with increasing the watermelon fruits sizes. It indicated that when the watermelon fruits size varies from small size $(5.0 \mathrm{~kg})$ to large size $(11.0$ $\mathrm{kg}$ ), the geometric mean diameter of the watermelon fruits increased from $20.70 \pm 0.074$ to $26.08 \pm 0.210 \mathrm{~cm}$. These results were in agreement with those obtained by Sadrnia et al. (2006).

Table (2) shows the mass, surface area, volume, density and thickness of rind of the watermelon fruits. It could be seen that the mass of watermelon fruit value ranged from $5.00 \pm 0.087$ to $11.09 \pm 0.043 \mathrm{~kg}$ for different sizes of watermelon fruits. The surface area and volume of watermelon fruit values ranged from $1487.10 \pm 12.55$ to $2447.61 \pm 16.13$ $\mathrm{cm}^{2}$ and $5393.90 \pm 68.19$ to $11389.44 \pm 112.72 \mathrm{~cm}^{3}$ for small and large 
size, respectively. The highest value of surface area and volume of watermelon fruits were $2447.61 \pm 16.13 \mathrm{~cm}^{2}$ and $11389.44 \pm 112.72 \mathrm{~cm}^{3}$ were found for large sizes, while, the lowest value of area and volume of watermelon fruits were $1487.10 \pm 12.55 \mathrm{~cm}^{2}$ and $5393.90 \pm 68.19 \mathrm{~cm}^{3}$ were obtained for small size of watermelon fruits. Surface area of watermelon fruits is important in handling and processing operations.

The results indicated that the density of the watermelon fruits increases with increasing the watermelon fruits sizes. It indicated that when the watermelon fruits size varies from small size $(5.0 \mathrm{~kg})$ to large size $(11.0$ $\mathrm{kg}$ ), the density of the watermelon fruits increased from $927.84 \pm 11.14$ to $973.57 \pm 11.35 \mathrm{~kg} \mathrm{~m}^{-3}$.

Table (2): The mean, standard deviation and coefficient of variation for some physical properties of watermelon fruits.

\begin{tabular}{|c|c|c|c|c|c|c|}
\hline \multicolumn{2}{|c|}{ Watermelon size } & $\begin{array}{c}\text { Mass, } \\
\mathrm{kg}\end{array}$ & $\begin{array}{c}\text { Surface } \\
\mathrm{area}, \mathrm{cm}^{2}\end{array}$ & $\begin{array}{c}\text { Volume, } \\
\mathrm{cm}^{3}\end{array}$ & $\begin{array}{c}\text { Density, } \\
\mathrm{kg} \mathrm{m}^{-3}\end{array}$ & $\begin{array}{c}\text { Thickness of } \\
\mathrm{rind}, \mathrm{mm}\end{array}$ \\
\hline \multirow{3}{*}{$\begin{array}{c}\text { Small } \\
\text { Size }\end{array}$} & Mean & 5.00 & 1487.10 & 5393.90 & 927.84 & 12.11 \\
\cline { 2 - 7 } & $\mathrm{SD}$ & 0.087 & 12.55 & 68.19 & 11.14 & 0.282 \\
\hline \multirow{3}{*}{$\begin{array}{c}\text { Medium } \\
\text { Size }\end{array}$} & Mean & 0.017 & 0.008 & 0.013 & 0.012 & 0.023 \\
\cline { 2 - 7 } & $\mathrm{SD}$ & 0.067 & 14.39 & 89.63 & 18.35 & 0.483 \\
\cline { 2 - 7 } & $\mathrm{CV}$ & 0.008 & 0.007 & 0.011 & 0.018 & 0.026 \\
\hline \multirow{3}{*}{$\begin{array}{c}\text { Large } \\
\text { Size }\end{array}$} & $\mathrm{Mean}$ & 11.09 & 2447.61 & 11389.44 & 973.57 & 20.28 \\
\cline { 2 - 7 } & $\mathrm{SD}$ & 0.043 & 16.13 & 112.72 & 11.35 & 0.599 \\
\cline { 2 - 7 } & $\mathrm{CV}$ & 0.004 & 0.007 & 0.010 & 0.012 & 0.030 \\
\hline
\end{tabular}

The results also indicated that the thickness of rind of the watermelon fruits increases with increasing the watermelon fruits sizes. It indicated that when the watermelon fruits size varies from small size $(5.0 \mathrm{~kg})$ to large size $(11.0 \mathrm{~kg})$, the thickness of rind of the watermelon fruits increased from $12.11 \pm 0.282$ to $20.28 \pm 0.599 \mathrm{~mm}$.

Table (3) and figures (2a, b and c) show the mass and moisture content of flesh, seeds and rind and of the watermelon fruits. It could be seen that the mass of flesh, seeds and rind of watermelon fruit values ranged from $2.929 \pm 0.092$ to $6.277 \pm 0.240 \mathrm{~kg}, 0.096 \pm 0.008$ to $0.208 \pm 0.042 \mathrm{~kg}$ and $1.992 \pm 0.069$ to $4.603 \pm 0.285 \mathrm{~kg}$, respectively, for different sizes of watermelon fruits. 
Regarding the moisture content of the different component of watermelon fruit. It was found that the moisture content of the flesh were 1.92, 179 and 1.77 times of the seeds, respectively, for different sizes of watermelon fruits, when it were $93.29 \pm 1.025,91.81 \pm 1.353$ and $91.57 \pm$ $0.576 \%$ of flesh, respectively, for different sizes of watermelon fruits and $48.69 \pm 0.610,51.29 \pm 2.959$ and $51.87 \pm 2.648 \%$ of seeds, respectively, for different sizes of watermelon fruits. The moisture content of the rind were $1.93,1.82$ and 1.78 times of the seeds, respectively, for different sizes of watermelon fruits, when it were $93.32 \pm 0.610,93.45 \pm 0.722$ and $91.90 \pm 0.180 \%$ of rind, respectively, for different sizes of watermelon fruits.

Table (3): The mean, standard deviation and coefficient of variation for some physical properties of watermelon fruits.

\begin{tabular}{|c|c|c|c|c|c|c|c|}
\hline \multicolumn{2}{|c|}{ Watermelon size } & \multicolumn{3}{|c|}{ Mass, $\mathrm{kg}$} & \multicolumn{3}{|c|}{ Moisture content, $\%$} \\
\hline & & Flesh & Seeds & Rind & Flesh & Seeds & Rind \\
\hline \multirow{3}{*}{$\begin{array}{l}\text { Small } \\
\text { Size }\end{array}$} & Mean & 2.929 & 0.096 & 1.992 & 93.29 & 48.69 & 93.32 \\
\hline & SD & 0.091 & 0.008 & 0.069 & 1.025 & 3.379 & 0.610 \\
\hline & $\mathrm{CV}$ & 0.031 & 0.079 & 0.035 & 0.011 & 0.069 & 0.007 \\
\hline \multirow{3}{*}{$\begin{array}{c}\text { Medium } \\
\text { Size }\end{array}$} & Mean & 4.758 & 0.139 & 3.141 & 91.81 & 51.29 & 93.45 \\
\hline & SD & 0.146 & 0.028 & 0.190 & 1.353 & 2.959 & 0.722 \\
\hline & $\mathrm{CV}$ & 0.031 & 0.201 & 0.060 & 0.015 & 0.058 & 0.008 \\
\hline \multirow{3}{*}{$\begin{array}{l}\text { Large } \\
\text { Size }\end{array}$} & Mean & 6.277 & 0.208 & 4.603 & 91.57 & 51.87 & 91.90 \\
\hline & $\mathrm{SD}$ & 0.240 & 0.042 & 0.285 & 0.576 & 2.648 & 0.180 \\
\hline & $\mathrm{CV}$ & 0.038 & 0.202 & 0.062 & 0.006 & 0.051 & 0.002 \\
\hline
\end{tabular}

Figure (2a): Mass of flesh of watermelon fruits for small size 


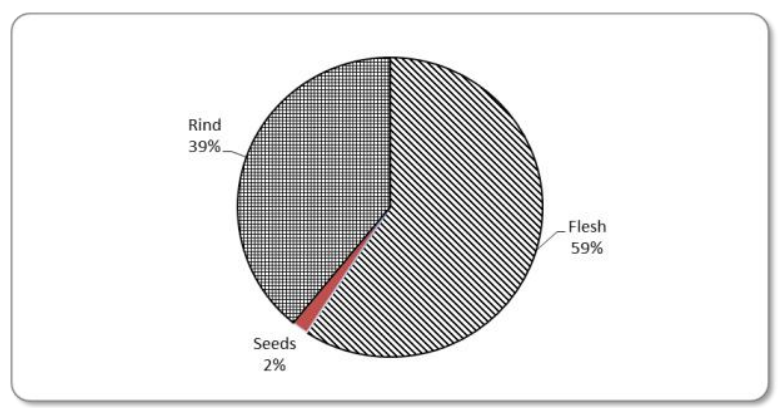

Figure (2b): Mass of flesh of watermelon fruits for medium size

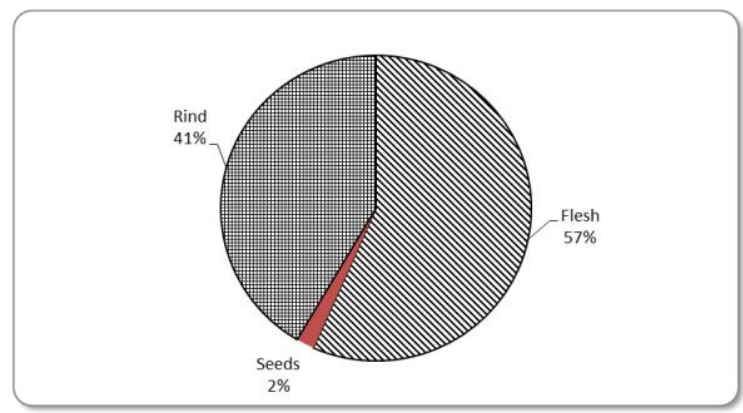

Figure (2c): Mass of flesh of watermelon fruits for large size

\subsection{Mechanical properties}

Table (4) shows the repose angle and crushing load of the watermelon fruits. The results indicated that the repose angle of the watermelon fruits increases with increasing the watermelon fruits sizes. It indicated that when the watermelon fruits size varies from small size $(5.0 \mathrm{~kg})$ to large size $(11.0 \mathrm{~kg})$, the repose angle of the watermelon fruits increased from $49.67 \pm 2.082$ to $71.00 \pm 0.028^{\circ}$.

Table (4): The mean, standard deviation and coefficient of variation for mechanical properties of watermelon fruits.

\begin{tabular}{|c|c|c|c|}
\hline \multicolumn{2}{|c|}{ Watermelon size } & Repose angle & Crushing load, kN \\
\hline \multirow{2}{*}{$\begin{array}{c}\text { Small } \\
\text { Size }\end{array}$} & Mean & 49.67 & 2.333 \\
\cline { 2 - 4 } & SD & 2.082 & 0.058 \\
\cline { 2 - 4 } & $\mathrm{CV}$ & 0.042 & 0.025 \\
\hline \multirow{3}{*}{$\begin{array}{c}\text { Medium } \\
\text { Size }\end{array}$} & Mean & 64.67 & 2.867 \\
\cline { 2 - 4 } & $\mathrm{SD}$ & 0.577 & 0.058 \\
\cline { 2 - 4 } & $\mathrm{CV}$ & 0.009 & 0.020 \\
\hline \multirow{2}{*}{$\begin{array}{c}\text { Large } \\
\text { Size }\end{array}$} & Mean & 71.00 & 4.600 \\
\cline { 2 - 4 } & $\mathrm{SD}$ & 2.000 & 0.265 \\
\cline { 2 - 4 } & $\mathrm{CV}$ & 0.028 & 0.058 \\
\hline
\end{tabular}


The results indicated that the crushing load of the watermelon fruits increases with increasing the watermelon fruits sizes. It indicated that when the watermelon fruits size varies from small size $(5.0 \mathrm{~kg})$ to large size $(11.0 \mathrm{~kg})$, the crushing load of the watermelon fruits increased from $2.333 \pm 0.058$ to $4.600 \pm 0.265 \mathrm{kN}$.

\subsection{Effect of storage temperature on physical and mechanical properties:}

\subsubsection{Dimensions change:}

Figure (3) shows the effect of different storage temperatures on change in length of watermelon fruits during storage. The results indicated that the change of watermelon fruits length decreases with increasing storage temperature and increasing storage time, where, it decreased from 22.081 to $21.55 \mathrm{~cm}$ (2.40\%), 26.539 to $25.903 \mathrm{~cm}(2.39 \%)$ and 28.556 to 27.850 $\mathrm{cm}(2.47 \%)$ for fruits size small size $(5.0 \mathrm{~kg})$, medium size $(8.0 \mathrm{~kg})$ and large size $(11.0 \mathrm{~kg})$, respectively, at storage temperature $30{ }^{\circ} \mathrm{C}$ after 45 days storage. The change of watermelon fruits length decreased from 22.930 to $22.317 \mathrm{~cm}$ (2.67\%), 27.177 to $26.539 \mathrm{~cm} \mathrm{(2.35 \% )} \mathrm{and} 28.768$ to $28.050 \mathrm{~cm}(2.50 \%)$ for fruits small size $(5.0 \mathrm{~kg})$, medium size $(8.0 \mathrm{~kg})$ and large size $(11.0 \mathrm{~kg})$, at storage temperature $15{ }^{\circ} \mathrm{C}$ after 65 days storage.

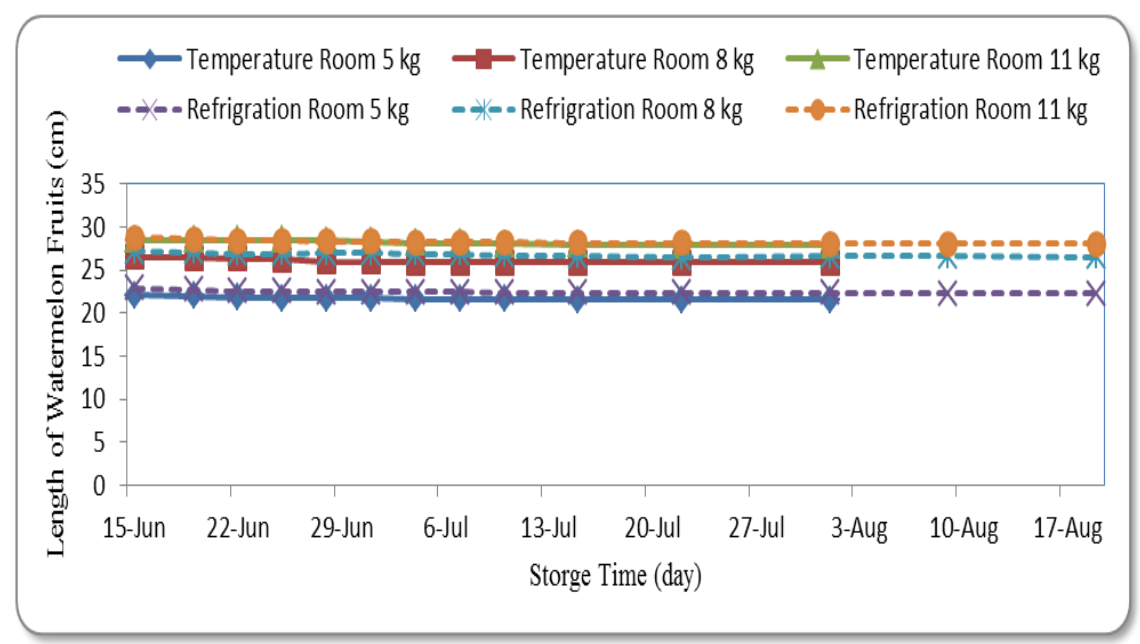

Figure (3): The effect of different storage temperatures on change in length of watermelon fruits during storage. 
Multiple regression analysis was carried out to get a relationship between the length changes of watermelon fruits (LC), fruit sizes (FS) and storage temperature (ST). The best form was as follows:

$$
\mathrm{LC}=18.178+1.0239 \mathrm{FS}-0.0336 \mathrm{ST} \quad \mathrm{R}^{2}=0.94 \quad \text { (3) } \mathrm{W}
$$

here:

LC is the length change of watermelon fruits, $\mathrm{cm}$

FS is the watermelon fruit sizes

ST is the storage temperature, ${ }^{\circ} \mathrm{C}$

Figure (4) shows the effect of different storage temperatures on change in major diameter of watermelon fruits during storage. The results indicated that the change of watermelon fruits major diameter were $0.327,0.379$ and $0.425 \mathrm{~cm}$ for small size $(5.0 \mathrm{~kg})$, medium size $(8.0 \mathrm{~kg})$ and large size $(11.0 \mathrm{~kg})$ watermelon fruit weight, respectively, at $30{ }^{\circ} \mathrm{C}$ storage temperature. The results also indicated that the change of watermelon fruits major diameter were $0.430,0.640$ and $0.670 \mathrm{~cm}$ for small size $(5.0$ $\mathrm{kg})$, medium size $(8 \mathrm{~kg})$ and large size $(11.0 \mathrm{~kg})$ watermelon fruit weight, respectively, at $15{ }^{\circ} \mathrm{C}$ storage temperature.

Multiple regression analysis was carried out to get a relationship between the major diameter changes of watermelon fruits (DC), fruit sizes (FS) and storage temperature (ST). The best form was as follows:

$$
\mathrm{DC}=15.948+1.0425 \mathrm{FS}+0.0105 \mathrm{ST} \quad \mathrm{R}^{2}=0.98
$$

Where:

$\mathrm{DC}$ is the major diameter change of watermelon fruits, $\mathrm{cm}$

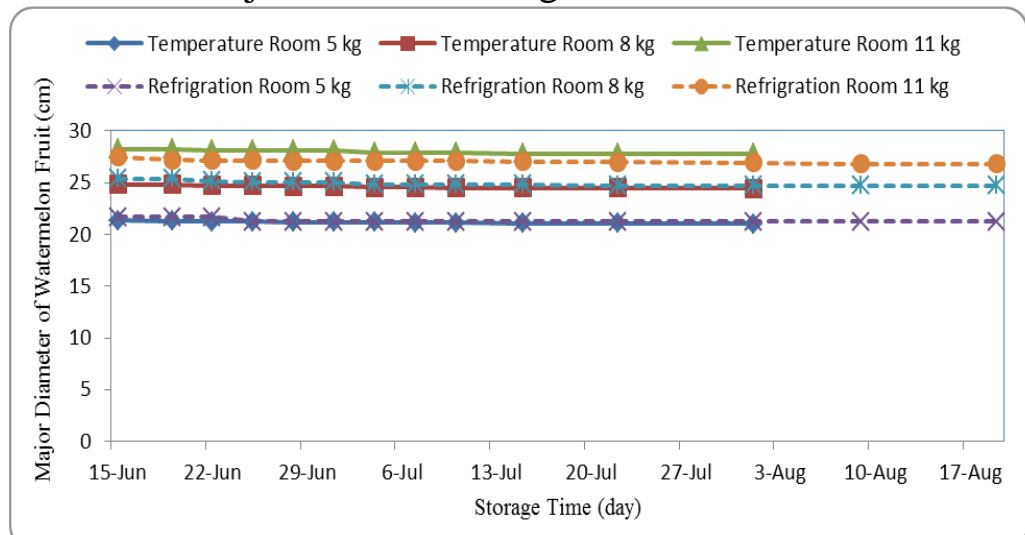

Figure (4): The effect of different storage temperatures on change in major diameter of watermelon fruits during storage. 


\subsubsection{Weight loss:}

Figure (5) shows the effect of different storage temperatures on weight loss of watermelon fruits during storage. The results indicated that the watermelon fruits weight decreased from 4.889 to $4.251 \mathrm{~kg}$ (13.05\%), 8.126 to $7.162 \mathrm{~kg}(11.86 \%)$ and 10.734 to $9.308 \mathrm{~kg}(13.28 \%)$ for fruits size small size $(5.0 \mathrm{~kg})$, medium size $(8.0 \mathrm{~kg})$ and large size $(11.0 \mathrm{~kg})$, respectively, at storage temperature $30{ }^{\circ} \mathrm{C}$ after 45 days storage. The watermelon fruits weight loss decreased from 4.932 to $4.595 \mathrm{~kg}(6.83 \%)$, 7.952 to $7.501 \mathrm{~kg}(5.67 \%)$ and 10.288 to $9.794 \mathrm{~kg}(4.80 \%)$ for small size $(5.0 \mathrm{~kg})$, medium size $(8 \mathrm{~kg})$ and large size $(11.0 \mathrm{~kg})$ watermelon fruit weight, respectively, at storage temperature $15^{\circ} \mathrm{C}$ after 65 days storage. The results also indicated that the watermelon fruits weight loss increases with increasing watermelon fruits size. It indicates that when the watermelon fruit weight increased from small size $(5 \mathrm{~kg})$ to large size (11 $\mathrm{kg}$ ), the watermelon fruit weight loss increased from 0.638 to $1.426 \mathrm{~kg}$ and 0.337 to $0.494 \mathrm{~kg}$ for 27 and $15{ }^{\circ} \mathrm{C}$ storage temperature, respectively. This due to the large size fruits has a large surface area which has a great effect on water loss from the fruits.

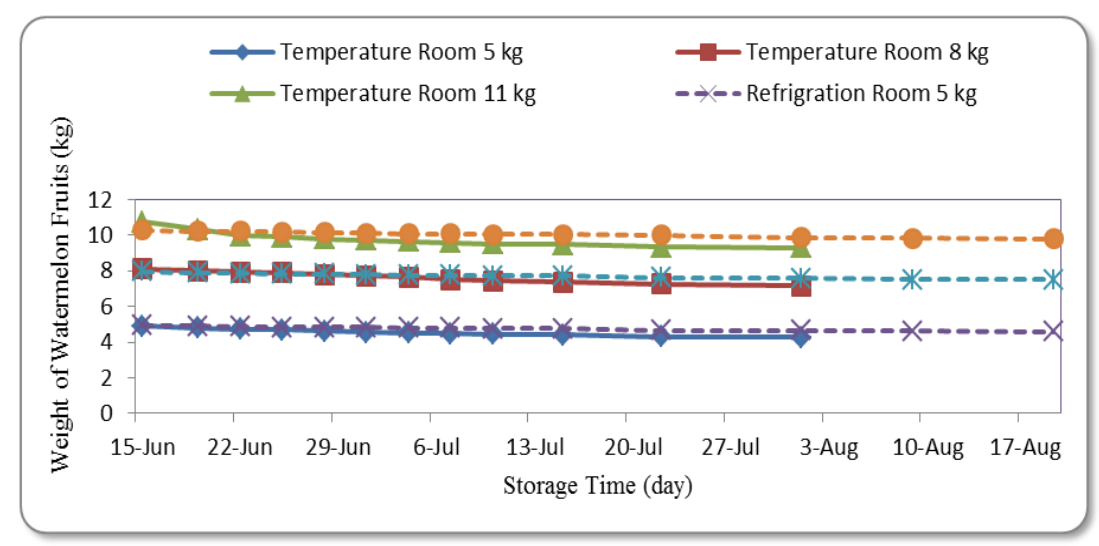

Figure (5): The effect of different storage temperatures on weight loss of watermelon fruits during storage.

The weight loss of the fruits stored at $30{ }^{\circ} \mathrm{C}$ was higher than that of the fruits stored $15^{\circ} \mathrm{C}$, this because of the high vapor pressure deficit which is the main factor in water evaporation from the fruits at higher temperature storage room. 
Multiple regression analysis was carried out to get a relationship between the weight losses of watermelon fruits (WL), fruit sizes (FS) and storage temperature (ST). The best form was as follows:

$$
\mathrm{WL}=0.705+0.877 \mathrm{FS}-0.013 \mathrm{ST} \quad \mathrm{R}^{2}=0.98
$$

Where:

WL is the weight loss of watermelon fruits, $\mathrm{kg}$

\subsubsection{Surface area change:}

Table (5) shows the effect of different storage temperatures on change in watermelon fruit surface area. The results indicated that the surface area change increases with decreasing storage temperature and increasing watermelon fruit sizes, where, it decreased from $1480.15 \pm 50.385$ to $1401.80 \pm 64.771 \mathrm{~cm}^{2}(5.29 \%)$ and $1561.22 \pm 80.009$ to $1480.60 \pm 81.584$ $\mathrm{cm}^{2}(6.65 \%)$ with the storage temperatures decreased from 30 to $15^{\circ} \mathrm{C}$, respectively at small size of watermelon fruits.

Table (5): The effect of different storage temperatures on change in surface area of watermelon fruits during storage.

\begin{tabular}{|c|c|c|c|c|c|}
\hline \multicolumn{2}{|c|}{ Watermelon size } & \multicolumn{3}{|c|}{ Watermelon fruits surface area change, $\mathrm{cm}^{2}$} \\
\cline { 3 - 6 } \multicolumn{2}{|c|}{} & \multicolumn{2}{|c|}{ Storage at $30^{\circ} \mathrm{C}$} & \multicolumn{2}{c|}{ Storage at $15^{\circ} \mathrm{C}$} \\
\cline { 2 - 6 } & Before & after & Before & After \\
\hline \multirow{3}{*}{$\begin{array}{c}\text { Small } \\
\text { Size }\end{array}$} & Mean & 1480.15 & 1401.80 & 1561.22 & 1480.60 \\
\cline { 2 - 6 } & SD & 50.385 & 64.771 & 80.009 & 81.584 \\
\cline { 2 - 6 } & CV & 0.034 & 0.046 & 0.051 & 0.055 \\
\hline \multirow{2}{*}{$\begin{array}{c}\text { Medium } \\
\text { Size }\end{array}$} & Mean & 2073.96 & 1996.84 & 2167.70 & 2063.83 \\
\cline { 2 - 6 } & SD & 140.170 & 101.532 & 26.277 & 25.635 \\
\cline { 2 - 6 } & CV & 0.068 & 0.051 & 0.012 & 0.012 \\
\hline \multirow{2}{*}{$\begin{array}{c}\text { Large } \\
\text { Size }\end{array}$} & Mean & 2532.16 & 2485.09 & 2485.06 & 2401.41 \\
\cline { 2 - 6 } & SD & 43.409 & 42.912 & 42.908 & 42.188 \\
\cline { 2 - 6 } & CV & 0.017 & 0.017 & 0.017 & 0.018 \\
\hline
\end{tabular}

The results indicated that the surface area change decreased from 2073.96 \pm 140.170 to $1999.84 \pm 101.582 \mathrm{~cm}^{2}(3.17 \%)$ and $2167.70 \pm 26.277$ to $2063.83 \pm 25.635 \mathrm{~cm}^{2}(3.86 \%)$ with the storage temperatures decreased from 30 to $15^{\circ} \mathrm{C}$, respectively at medium size of watermelon fruits. The results also indicated that the surface area change decreased from 2532.16 \pm 43.409 to $2485.09 \pm 42.912 \mathrm{~cm}^{2}(1.86 \%)$ and $2485.06 \pm 42.908$ to $2401.41 \pm 42.188 \mathrm{~cm}^{2}(3.24 \%)$ with the storage temperatures decreased from 30 to $15^{\circ} \mathrm{C}$, respectively at large size of watermelon fruits. 
The results indicated that the change of watermelon fruits surface area decreases with increasing watermelon fruits size. It indicates that when the watermelon fruit weight increased from small size $(5.0 \mathrm{~kg})$ to large size $(11.0 \mathrm{~kg})$, the watermelon fruit surface area change decreased from $78.35 \pm 23.55 \mathrm{~cm}^{2}(5.29 \%)$ to $47.07 \pm 16.29 \mathrm{~cm}^{2}(1.86 \%)$ and $103.87 \pm$ $25.86 \mathrm{~cm}^{2}(6.65 \%)$ to $80.62 \pm 12.28 \mathrm{~cm}^{2}(3.24 \%)$ for 30 and $15{ }^{\circ} \mathrm{C}$ storage temperature, respectively.

\subsubsection{Volume change:}

Table (6) shows the effect of different storage temperatures on change in watermelon fruit volume. The results indicated that the volume change increases with decreasing storage temperature and increasing watermelon fruit sizes, where, it decreased from $5326.23 \pm 274.746$ to $4939.08 \pm$ $343.379 \mathrm{~cm}^{3}(7.83 \%)$ and $5804.49 \pm 443.707$ to $5362.55 \pm 439.595 \mathrm{~cm}^{3}$ $(8.13 \%)$ with the storage temperatures decreased from 30 to $15^{\circ} \mathrm{C}$, respectively at small size of watermelon fruits.

The results indicated that the volume change decreased from $8891.51 \pm$ 891.759 to $8398.09 \pm 638.50 \mathrm{~cm}^{3}(4.65 \%)$ and $9490.49 \pm 172.560$ to $8818.82 \pm 164.316 \mathrm{~cm}^{3}(4.66 \%)$ with the storage temperatures decreased from 30 to $15^{\circ} \mathrm{C}$, respectively at medium size of watermelon fruits. The results also indicated that the volume change decreased from $11982.38 \pm$ 308.514 to $11652.75 \pm 308.41 \mathrm{~cm}^{3}(2.75 \%)$ and $11649.66 \pm 301.288$ to $11069.19 \pm 291.249 \mathrm{~cm}^{3}(3.27 \%)$ with the storage temperatures decreased from 30 to $15^{\circ} \mathrm{C}$, respectively at large size of watermelon fruits.

Table (6): The effect of different storage temperatures on change in volume of watermelon fruits during storage.

\begin{tabular}{|c|c|c|c|c|c|}
\hline \multicolumn{2}{|c|}{ Watermelon size } & \multicolumn{3}{|c|}{ Watermelon fruits volume change, $\mathrm{cm}^{3}$} \\
\cline { 3 - 6 } \multicolumn{2}{|c|}{} & \multicolumn{2}{|c|}{ Storage at $30^{\circ} \mathrm{C}$} & \multicolumn{2}{c|}{ Storage at $15^{\circ} \mathrm{C}$} \\
\cline { 3 - 6 } & Before & After & Before & After \\
\hline \multirow{3}{*}{ Small Size } & Mean & 5356.23 & 4939.08 & 5804.49 & 5362.55 \\
\cline { 2 - 6 } & SD & 274.746 & 343.379 & 443.707 & 439.595 \\
\cline { 2 - 6 } & CV & 0.051 & 0.069 & 0.076 & 0.082 \\
\hline \multirow{3}{*}{$\begin{array}{c}\text { Medium } \\
\text { Size }\end{array}$} & Mean & 8891.51 & 8398.09 & 9490.49 & 8818.82 \\
\cline { 2 - 6 } & SD & 891.759 & 638.50 & 172.560 & 164.316 \\
\cline { 2 - 6 } & CV & 0.100 & 0.076 & 0.018 & 0.019 \\
\hline \multirow{3}{*}{\begin{tabular}{c} 
Large Size \\
\cline { 2 - 6 }
\end{tabular}} & Mean & 11982.38 & 11652.75 & 11649.66 & 11069.19 \\
\cline { 2 - 6 } & SD & 308.514 & 301.41 & 301.288 & 291.249 \\
\cline { 2 - 6 } & CV & 0.026 & 0.026 & 0.026 & 0.026 \\
\hline
\end{tabular}


The results indicated that the change of watermelon fruits volume decreases with increasing watermelon fruits size. It indicates that when the watermelon fruit weight increased from small size $(5.0 \mathrm{~kg})$ to large size $(11.0 \mathrm{~kg})$, the watermelon fruit volume change decreased from $417.15 \pm 120.12 \mathrm{~cm}^{3}(7.83 \%)$ to $329.64 \pm 115.23 \mathrm{~cm}^{3}(2.75 \%)$ and 471.67 $\pm 67.42 \mathrm{~cm}^{3}(8.13 \%)$ to $380.47 \pm 96.12 \mathrm{~cm}^{3}(3.27 \%)$ for 30 and $15{ }^{\circ} \mathrm{C}$ storage temperature, respectively.

\subsubsection{Density change:}

Table (7) shows the effect of different storage temperatures on change in watermelon fruit density. The results indicated that the density change increases with decreasing storage temperature and increasing watermelon fruit sizes, where, it decreased from $913.63 \pm 31.263$ to $862.38 \pm 36.109$ $\mathrm{kg} \mathrm{m}^{-3}(5.61 \%)$ and $857.69 \pm 20.146$ to $850.32 \pm 31.342 \mathrm{~cm}^{3}(2.10 \%)$ with the storage temperatures decreased from 30 to $15^{\circ} \mathrm{C}$, respectively at small size of watermelon fruits.

The results indicated that the change of watermelon fruits density increases with increasing watermelon fruits size. It indicates that when the watermelon fruit weight increased from small size $(5.0 \mathrm{~kg})$ to large size $(11.0 \mathrm{~kg})$, the watermelon fruit volume change decreased from $51.24 \pm$ 21.17 to $96.82 \pm 23.26 \mathrm{~kg} \mathrm{~m}^{-3}$ and $18.01 \pm 1.99$ to $45.78 \pm 1.87 \mathrm{~kg} \mathrm{~m}^{-3}$ for 30 and $15{ }^{\circ} \mathrm{C}$ storage temperature, respectively.

Table (7): The effect of different storage temperatures on change in density of watermelon fruits during storage.

\begin{tabular}{|c|c|c|c|c|c|}
\hline \multirow{2}{*}{ Watermelon size } & \multicolumn{3}{|c|}{ Watermelon fruits density change, $\mathrm{kg} \mathrm{m}^{-3}$} \\
\cline { 3 - 6 } & \multicolumn{2}{|c|}{ Storage at $30^{\circ} \mathrm{C}$} & \multicolumn{2}{c|}{ Storage at $15^{\circ} \mathrm{C}$} \\
\cline { 2 - 6 } & Before & after & Before & After \\
\hline \multirow{3}{*}{$\begin{array}{c}\text { Small } \\
\text { Size }\end{array}$} & Mean & 913.63 & 862.38 & 857.69 & 850.32 \\
\cline { 2 - 6 } & SD & 31.263 & 36.109 & 20.146 & 31.342 \\
\cline { 2 - 6 } & $\mathrm{CV}$ & 0.034 & 0.042 & 0.023 & 0.037 \\
\hline \multirow{3}{*}{$\begin{array}{c}\text { Medium } \\
\text { Size }\end{array}$} & Mean & 916.47 & 853.47 & 850.74 & 837.67 \\
\cline { 2 - 6 } & $\mathrm{SD}$ & 37.865 & 25.444 & 38.829 & 19.432 \\
\cline { 2 - 6 } & $\mathrm{CV}$ & 0.041 & 0.030 & 0.046 & 0.023 \\
\hline \multirow{3}{*}{$\begin{array}{c}\text { Large } \\
\text { Size }\end{array}$} & Mean & 895.88 & 799.06 & 885.45 & 884.35 \\
\cline { 2 - 6 } & $\mathrm{SD}$ & 9.931 & 18.181 & 90.269 & 93.042 \\
\cline { 2 - 6 } & $\mathrm{CV}$ & 0.011 & 0.023 & 0.102 & 0.105 \\
\hline
\end{tabular}




\subsubsection{Effect of storage temperature on the crushing load of watermelon fruits:}

Table (8) shows the effect of storage temperature on the crushing load of the watermelon fruits. The results indicated that the crushing load of the watermelon fruits decreases with decreasing storage temperature and decreasing watermelon fruit sizes, where, it decreased from $2.33 \pm 0.058$ to $1.20 \pm 0.100 \mathrm{kN}(48.63 \%)$ and $2.33 \pm 0.058$ to $1.67 \pm 0.153 \mathrm{kN}$ $(28.63 \%)$ with the storage temperatures decreased from 30 to $15^{\circ} \mathrm{C}$, respectively at small size of watermelon fruits.

The results indicated that the change of watermelon fruits crushing load increases with increasing watermelon fruits size. It indicates that when the watermelon fruit weight increased from small size $(5.0 \mathrm{~kg})$ to large size $(11.0 \mathrm{~kg})$, the watermelon fruit crushing load increased from $1.133 \pm$ 0.053 to $2.333 \pm 0.231 \mathrm{kN}(51.44 \%)$ and $0.667 \pm 0.153$ to $1.700 \pm 0.346$ $\mathrm{kN}(60.76 \%)$ for 30 and $15{ }^{\circ} \mathrm{C}$ storage temperature, respectively. These results were in agreement with those obtained by Bahnasawy and Khater (2014).

Table (8): The effect of storage temperature on the crushing load of the watermelon fruits.

\begin{tabular}{|c|c|c|c|c|c|}
\hline \multicolumn{2}{|c|}{ Watermelon size } & \multicolumn{3}{|c|}{ Watermelon fruits crushing load change, $\mathrm{kN}$} \\
\cline { 3 - 6 } \multicolumn{2}{|c|}{} & \multicolumn{2}{|c|}{ Storage at $30^{\circ} \mathrm{C}$} & \multicolumn{2}{c|}{ Storage at $15^{\circ} \mathrm{C}$} \\
\cline { 3 - 6 } & Before & after & Before & After \\
\hline \multirow{3}{*}{$\begin{array}{c}\text { Small } \\
\text { Size }\end{array}$} & Mean & 2.33 & 1.20 & 2.33 & 1.67 \\
\cline { 2 - 6 } & SD & 0.058 & 0.100 & 0.058 & 0.153 \\
\cline { 2 - 6 } & $\mathrm{CV}$ & 0.250 & 0.083 & 0.250 & 0.092 \\
\hline \multirow{3}{*}{$\begin{array}{c}\text { Medium } \\
\text { Size }\end{array}$} & Mean & 2.87 & 1.53 & 2.87 & 2.00 \\
\cline { 2 - 6 } & SD & 0.058 & 0.208 & 0.058 & 0.100 \\
\cline { 2 - 6 } & $\mathrm{CV}$ & 0.020 & 0.136 & 0.020 & 0.050 \\
\hline \multirow{2}{*}{$\begin{array}{c}\text { Large } \\
\text { Size }\end{array}$} & Mean & 4.60 & 2.27 & 4.60 & 2.90 \\
\cline { 2 - 6 } & SD & 0.265 & 0.208 & 0.265 & 0.100 \\
\cline { 2 - 6 } & CV & 0.058 & 0.092 & 0.058 & 0.034 \\
\hline
\end{tabular}

3.3.7. Effect of storage temperature on the marketable watermelon fruits:

Table (9) shows the effect of storage temperature on the marketable watermelon fruits. The results indicated that the marketable watermelon 
fruits increases with decreasing storage temperature and decreasing watermelon fruit sizes, where, it increased from $48.00 \pm 2.00$ to $90.00 \pm$ $1.33 \%$ with the storage temperatures decreased from 30 to $15^{\circ} \mathrm{C}$. On the other hand, marketable watermelon fruit decreased from $48.00 \pm 2.00$ to $25.00 \pm 6.70 \%$ for small size $(5.0 \mathrm{~kg})$ to large size $(11.0 \mathrm{~kg})$ of watermelon fruit weight, respectively at $30{ }^{\circ} \mathrm{C}$ storage temperature, but it decreased from $90.00 \pm 1.33$ to $75.67 \pm 5.50 \%$ for small size $(5.0 \mathrm{~kg})$ to large size $(11.0 \mathrm{~kg})$ of watermelon fruit weight, respectively at $15{ }^{\circ} \mathrm{C}$ storage temperature. These results were in agreement with those obtained by Risse et al. (1990).

Marketability percentages of the fruit stored at $30{ }^{\circ} \mathrm{C}$ were $48.00,27.00$ and $25.00 \%$ at different sizes (small, medium and large, respectively), which means one ton of these fruits will loss 52,73 and $75 \%$ of its prices after storage for 45 days. The price of one ton of watermelon fruits is L.E 2000. By the end of storage, the farmer will loss L.E 1040, 1460 and 1500 for small size, medium size and large size of watermelon fruits, respectively. On the other hand, marketability percentages of the fruit stored at $15{ }^{\circ} \mathrm{C}$ were $90.00,80.50$ and $75.67 \%$ at different sizes, which means the one ton of these fruits will loss $10.00,19.50$ and $24.33 \%$ of its prices after storage for 65 days. By the end of storage, the farmer will loss L.E 200, 390 and 486.6 for small size, medium size and large size of watermelon fruits, respectively.

Table (9): The effect of storage temperature on the marketable watermelon fruits.

\begin{tabular}{|c|c|c|c|}
\hline \multicolumn{2}{|c|}{ Watermelon size } & \multicolumn{2}{|c|}{ Marketable watermelon fruits, \% } \\
\cline { 3 - 4 } \multicolumn{2}{|c|}{} & $30{ }^{\circ} \mathrm{C}$ & $15^{\circ} \mathrm{C}$ \\
\hline \multirow{3}{*}{$\begin{array}{c}\text { Small } \\
\text { Size }\end{array}$} & Mean & 48.00 & 90.00 \\
\cline { 2 - 4 } & SD & 2.00 & 1.33 \\
\cline { 2 - 4 } & $\mathrm{CV}$ & 0.042 & 0.015 \\
\hline \multirow{3}{*}{$\begin{array}{c}\text { Medium } \\
\text { Size }\end{array}$} & Mean & 27.00 & 80.50 \\
\cline { 2 - 4 } & $\mathrm{SD}$ & 6.45 & 5.00 \\
\cline { 2 - 4 } & $\mathrm{CV}$ & 0.239 & 0.062 \\
\hline \multirow{2}{*}{$\begin{array}{c}\text { Large } \\
\text { Size }\end{array}$} & Mean & 25.00 & 75.67 \\
\cline { 2 - 4 } & $\mathrm{SD}$ & 6.70 & 5.50 \\
\cline { 2 - 4 } & $\mathrm{CV}$ & 0.268 & 0.073 \\
\hline
\end{tabular}




\section{CONCLUSIONS}

The experiment was carried out to study the physical and mechanical properties of watermelon fruits before and after storage under different storage temperatures $\left(15\right.$ and $30^{\circ} \mathrm{C}$ ) for three categories [5 $\mathrm{kg}$ (small), 8 $\mathrm{kg}$ (medium) and $11 \mathrm{~kg}$ (large)]. The obtained results can be summarized as follows:

- The length, major diameter and minor diameter of watermelon fruit value ranged from 22.18 to $28.77 \mathrm{~cm}, 21.34$ to $27.07 \mathrm{~cm}$ and 18.92 to $23.01 \mathrm{~cm}$, respectively. The spherical coefficient and the geometric mean diameter of the watermelon fruits decreased from 0.933 to 0.907 and 20.70 to $26.08 \mathrm{~cm}$, respectively.

- The surface area and volume of watermelon fruit values ranged from 1487.10 to $2447.61 \mathrm{~cm}^{2}$ and 5393.90 to $11389.44 \mathrm{~cm}^{3}$, respectively. The density of the watermelon fruits ranged from 927.84 to $973.57 \mathrm{~kg} \mathrm{~m}^{-3}$.

- The thickness of rind of the watermelon fruits ranged from 12.11 to 20.28 $\mathrm{mm}$. The mass of flesh, seeds and rind of watermelon fruit values ranged from 2.929 to $6.277 \mathrm{~kg}, 0.096$ to $0.208 \mathrm{~kg}$ and 1.992 to $4.603 \mathrm{~kg}$, respectively.

- The repose angle and the crushing load of the watermelon fruits increased from 49.67 to $71.00^{\circ}$ and 2.333 to $4.600 \mathrm{kN}$.

- The change of watermelon fruits dimensions decreased ranged from 2.40, 2.39 and $2.47 \%$ for fruits size small size $(5.0 \mathrm{~kg})$, medium size $(8.0 \mathrm{~kg})$ and large size $(11.0 \mathrm{~kg})$, respectively, at storage temperature $30^{\circ} \mathrm{C}$ and it decreased from 2.67, 2.35 and $2.50 \%$ for fruits small size, medium size and large size of watermelon fruit weight, at storage temperature $15^{\circ} \mathrm{C}$.

- The watermelon fruits weight decreased from 13.05, 11.86 and $13.28 \%$ for fruits size small size, medium size and large size, respectively, at storage temperature $30{ }^{\circ} \mathrm{C}$. It decreased from $6.83 \%, 5.67$ and $4.80 \%$ for small size, medium size and large size of watermelon fruit weight, respectively, at storage temperature $15^{\circ} \mathrm{C}$ after 65 days storage.

- The surface area and volume change increases with decreasing storage temperature and increasing watermelon fruit sizes. It decreased from 5.29 to $6.65 \%$ and 7.83 to $8.13 \%$, respectively, with the storage temperatures decreased from 30 to $15^{\circ} \mathrm{C}$, respectively at small size of watermelon fruits. 
- The crushing load of the watermelon fruits decreases with decreasing storage temperature and decreasing watermelon fruit sizes. It decreased from 48.63 to $28.63 \%$ with the storage temperatures decreased from 30 to $15^{\circ} \mathrm{C}$, respectively at small size of watermelon fruits.

- The marketable watermelon fruits increases with decreasing storage temperature and decreasing watermelon fruit sizes. It increased from 48.00 to $90.00 \%$ with the storage temperatures decreased from 30 to $15^{\circ} \mathrm{C}$.

\section{REFERENCES}

Ahmed, J., 1996. Studies on watermelon products. Indian Food Packer, 50: $15-20$.

Anonymous, 2014. Watermelon characteristics. http://www.ehow.com/info

ASAE Standard, 1984. ASAE 5352.1.moisture measurement. American Society of Agric. Eng. 2950 Niles Road, St. Joseph, MI 490859659.

Bahnasawy, A.H., El-Haddad, Z.A., El-Ansary, M.Y., Sorour H.M., 2004. Physical and mechanical properties of some Egyptian onion cultivars. J. of Food Eng., 62: 255-261.

Bahnasawy, A.H., Khater, E.G., 2014. Effect of wax coating on the quality of cucumber fruits during storage. J. Food Process. Technol. 5 (6): 339. doi:10.4172/2157-7110.1000339

Bawa, A.S., Bains, G.S., 1977. Integrated processing of watermelons for juice and seed. Indian Food Parker, 31: 12.

Chandrasekar, V., Viswanathan, R., 1999. Physical and thermal properties of coffee. J. Agric. Engng. Res., 73, 227-234.

Chisholm, D.N., Picha, D.H., 1986. Effect of storage on sugar and organic acid contents of watermelons. HortScience 21:1031- 1033.

Dow, A.T., Segall, R.H., Hopkins, D.L., Elmstrom, G.W., 1979. Effects of storage temperature and field fungicide treatments on decay of Florida watermelons. Proc. Fla. State Hort. Soc. 91:149150.

El-Raie, A.S., Hendawy, N.A., Taib, A.Z., 1996. Study of physical and engineering properties for some agricultural products. Misr J. of Agric.Engng., 13 (1):211-226. 
GAEO (General of Agricultural Economics organization) - Ministry of Agriculture and Land Reclamation, 2013. Acreage statistics and vegetable production in the Arab Republic of Egypt (unpublished).

Gosh, B.N., 1969. Physical properties of the different grades of arabica beans. Transactions of the ASAE, 9(3):592-593.

Hardenburg, R.E., Watada, A.E., Wang, C.Y., 1986. The commercial storage of fruits, vegetables, and florist and nursery stocks. USDA Agr. Hdbk. 66.

Hour, S.S., Ahmed, E.M., Carter, R.D., 1980. Concentration of watermelon juice. J. Food Sci., 45: 718-719.

Irvine, D.A., Jayas, D.S., White, N.D.G., Britton M.G., 1992. Physical properties of flaxseed, lentils, fababeans. Can.. Agric. Engng, 34(1):75- 82.

Koocheki, A., Razavi, S.M.A., Milani, E., Monghadam, T.M., Alamatiyan, S., Izadkhah, S., 2007. Physical properties of watermelon seed as a function of moisture content and variety. Int. Agrophysics, 21: 349-359.

LeBlanc, D.I., Stark, R., MacNeil, B., Goguen, B., Beraulieu C., 1996. Perishable food temperature in retail stores. In: New Development in Refrigeration for Food Safety and Quality. International Institute Refrigeration Commision C2, 1996-6, 42-57.

Leupschen, N.S., 1961. The development of Mycosphaerella black rot and Pellicularia rolfsii rot of watermelons at various temperatures. Plant Dis. Rptr. 45:557-559.

Perkins-Veazie, P., Collins, J.K., 2004. Flesh quality and lycopene stability of fresh-cut watermelon. Postharvest Biol. Technol., 31: 159-166.

Perrin, P.W., Gaye, M.M., 1986. Effects of simulated retail display and overnight storage treatment on quality maintenance in fresh broccoli. J. Food Sci. 51, 146-149.

Picha, D.H., 1986. Postharvest fruit conditioning reduces chilling injury in watermelons. HortScience 21(6):1407-1409.

Risse, L.A., Breckt, L.K., Sargent, S.A., Locascio, S.J., Crall, J.M., Elmstrom, G.W., Maynard, D.N., 1990. Storage characteristics of 
small watermelon cultivars. J. Amer. Soc. Hort. Sci., 115 (3): 440 443.

Sadrnia, H., Rajabipour, A., Jafary, A., Javadi, A., Mostafi Y., 2006. Comparing physical and mechanical properties of two varieties of watermelon: Charleston Gray and Crimson Sweet. Energy efficiency and agricultural engineering. Proceedings of the union of scientists - Rousse, Third Conference, 7 - 9 June 2006. p. 360 367.

Şalk, A., Arin, L., Deveci, M., Polat S., 2008. Özel Sebzecilik (In Turkish). Namık Kemal Üniversitesi Ziraat Fakültesi Bahçe Bitkileri Bölümü, Tekirdağ, Turkey.

Showalter, R.K., 1960. Watermelon color as affected by maturity and storage. Proc. Fla. State Hort. Soc. 73:289-293.

Snedecor, G.W., Cochran, W.G., 1980. Statistical methods, $7^{\text {th }}(\mathrm{Ed})$, Iowa State Univ. Press, Ames, Iowa, USA.

الملخص العربي

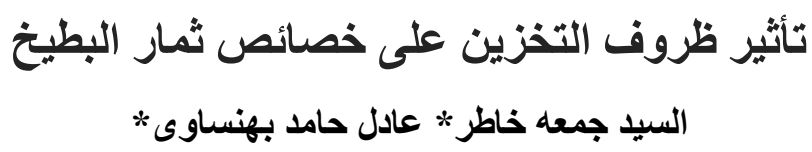

يهدف هذا البحث الى دراسة خصائص ثمار البطيخ قبل وبعد التخزين على درجات حرارة

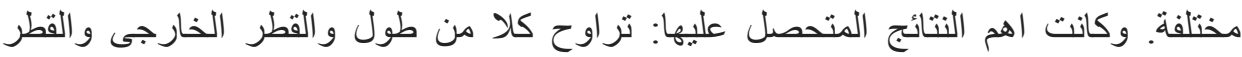

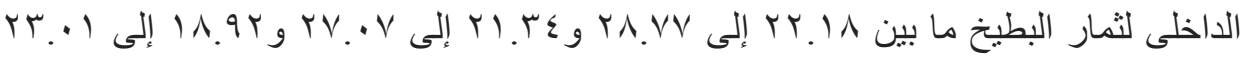

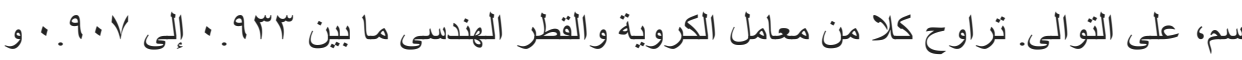

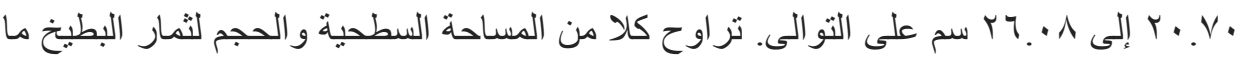

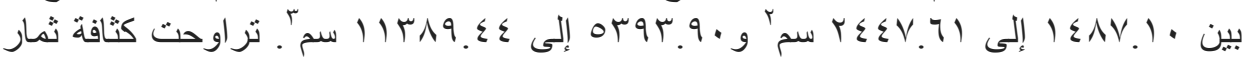

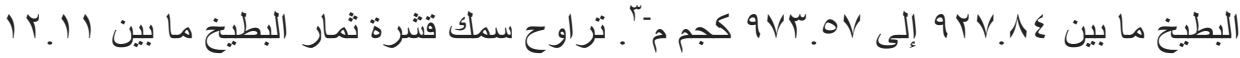

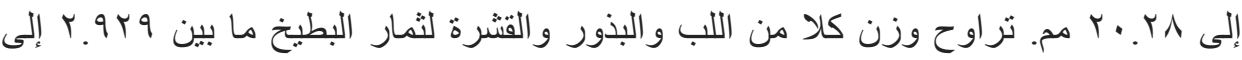

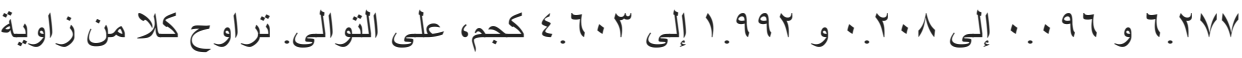

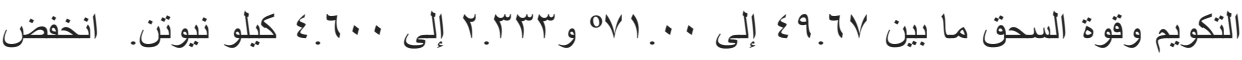

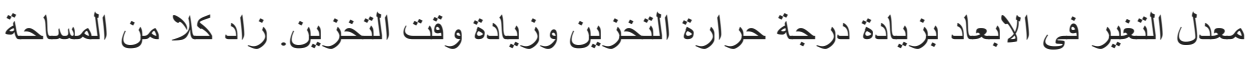

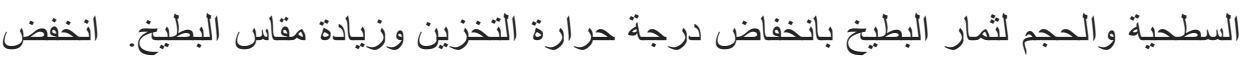

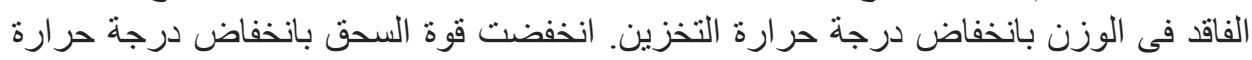

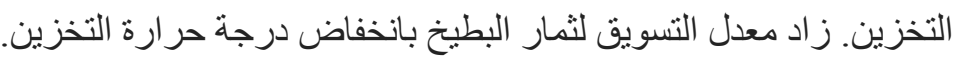

*قسم الهندسة الزراعية ـ كلية الزراعة بمشتهر - جامعة بنها. 